\title{
Preservation of manor and park ensembles within the capital city and the principles of "green architecture"
}

\author{
Igor Pryadko ${ }^{1, *}$ Igor Lebedev ${ }^{1}$ \\ ${ }^{1}$ Moscow State University of Civil Engineering (National Research University), Yaroslavskoye sh., \\ 26, 129337, Moscow, Russia
}

\begin{abstract}
The paper deals with certain issues related to the protection and restoration of estate and park complexes located in the territory of the Russian capital. Some legal aspects of this problem are touched upon. Examples include urban capital estates (such as the modernist-style estate owned by industrialists and textile magnates Nosov), as well as country estates formerly centers of local properties owned by representatives of privileged classes of imperial Russia. The history and modern state of the estates of Klenovo, the former estate of the princes of Cherkasy, and Valuevo, which belonged at the beginning of the XIX ${ }^{\text {th }}$ century to the county family Musin-Pushkin, and at the end of the XIX ${ }^{\text {th }}$ - the beginning of the $\mathrm{XX}^{\text {th }}$ century belonged to Lepeshkin's factories, are analyzed in detail. As the main methods, the authors use the method of retrospective analysis of legal sources, media reports, the comparative historical method, and conclusion by analogy.
\end{abstract}

\section{Introduction}

The work analyses the legal and architectural and urban planning aspects of the protection and restoration of urban estates within the city of Moscow. Since the estate-park ensemble includes both a park area and elements of small estate-park architecture, both residential buildings and alleys and pathways network, we consider the various activities produced by restoration workshops, tenants of architectural heritage sites and municipal authorities as activities to expand green areas in the capital region. Planting Erman birches or rare in the capital region Engelman fir-trees, smashing flower-beds according to ancient drawings, images, engravings and pictures, restorers make their own contribution to the increase of "green lungs" of the capital, to the increase of species diversity of plants and growth of recreational areas. However, in works considering the protection of garden and park ensembles in Moscow, the legal aspect of this problem is not always taken into account. This gap should be filled by this work.

The problem of restoration of monuments of history and architecture has a large number of approaches and interpretations. The history of the XXth century, and especially the domestic history, unfortunately did not contribute to their preservation. The violent events

* Corresponding author: priadcko.igor2011@yandex.ru 
of the 1920-1930's, the so-called "urbicide" of the Great Patriotic War period, the clearing of megacities for commercial real estate in the late 1990s proved to be destructive for entire arrays of historical buildings [1, s. 171-182]. A large number of buildings and constructions were destroyed due to tragic circumstances, due to neglect, human actions and natural disasters, as a result of trigger processes launched by industrialization in the early $\mathrm{XX}$ century. The barbaric destruction of cathedrals, churches, city estates and other historical monuments in the 1920-1930s in Soviet Russia is a vivid example of this (as domestic writers, historians and restorers wrote about with pain in their time [2, p. 131]). However, such events cannot be considered a thing of the distant past. More recently, the Church of Ascension in Kondopoga - the pearl of the wooden architecture of the Russian North - was lost [3, p.3]. Destruction of architectural monuments causes not only irreparable damage to historical memory, but also destroys the ecology of architectural and planning space. The authors proceed from the fact that the destruction of gardening complexes leads to the psychological degradation of landscapes. The inevitable is a progressive decline in the aesthetic qualities of the suburban and urban areas due to the depersonalization of modern buildings. The depersonalization is inadequate to the needs of people in the architectural and planning environment, etc.

The specific category of objects protected by the state is urban and suburban estates of the XVIII-XX centuries, located both on the territory of new districts of the Russian capital and on its former suburbs. All these objects are distinguished by the presence of green park arrays around them. Therefore, not only historical buildings, but also manor park ensembles around these monuments are subject to protection. On the territory of New Moscow there are such settlements as the villages Valuevo, Ostafyevo, Shchapovo, Klenovo and a number of others. After the great social coup of 1917, only some of these estates were institutions of the new power located, museums were located in several nationalized estates, and in other estates recreational facilities were placed. Most of the buildings were destroyed by nature and people.

For the long life of architectural complexes, by human standards, organizations, located in the walls of estates in the Soviet and post-Soviet era, have repeatedly changed. It is enough to cite as an example the "biography" of the estate of the textile manufacturer and the First Guild merchant V.D. Nosov, made in the early $\mathrm{XX}^{\text {th }}$ century in the Art Nouveau style. In the Soviet period, a kindergarten was located in the estate, and later the monument was given at the disposal of the Scientific Research Institute of Wool [4, p.12-13]. The fate of religious buildings was similar, only a small part of them remained operational, and many of them began to be used as warehouses, vegetable stores, archives, museums or other cultural institutions. For example, St. Nicholas Church in Naro-Fominsk near Moscow in the period of 1930-1990s. was used as a museum of local lore. Another St. Nicholas Cathedral, located in Klenovo, was much less fortunate: it housed a grain warehouse. In Soviet times, far from always the practice of placing third-party organizations contributed to the preservation of the monuments. According to the publicist, the merchant's mansion we already mentioned was "almost turned into ruins" by the numerous owners.

In some buildings belonging to the category of architectural monuments, government institutions or commercial organizations are now located. Responsibility for the preservation of historical buildings was transferred to government institutions and nongovernmental organizations and lies with these institutions and organizations.

Nevertheless, in the post-Soviet period and the first decade of the $\mathrm{XXI}^{\text {st }}$ century, the situation about such constructions became somewhat different. If earlier the irrational use of historical premises led to their slow destruction, today the main damage is caused to them by redevelopment and unskilled repairs, leading to the loss of a whole monument or its important fragments. An example of careful and competent use of the areas of historical 
buildings is the already mentioned the merchant Nosov's mansion on the Electrozavodskaya street.

Farm (Fig. 1, architect A. Menelaws, 1818), and Lama pavilion (Fig. 2, architect A. Menelaws, I. A. Ivanov, 1820 - 1822)..

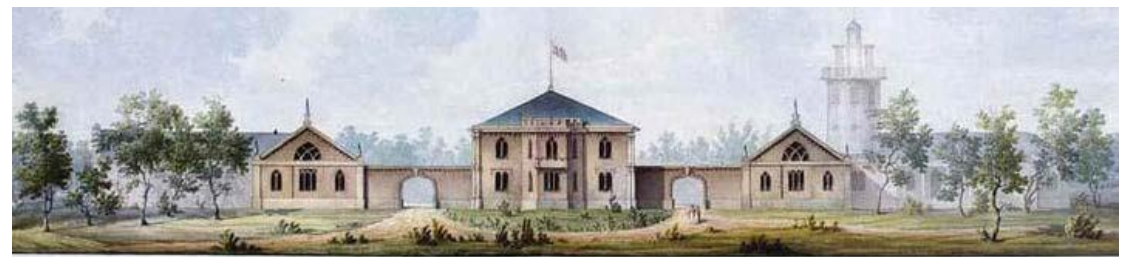

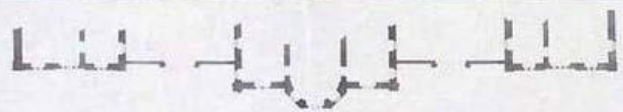

Fig. 1. Farm. Alexander Park. 1818 Architect A. Menelaws. Drawing. Facade. Plan

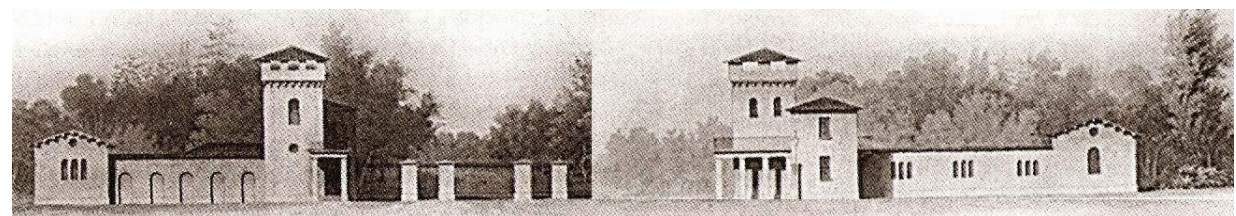

Fig. 2. Lama pavilion. Alexander Park. 1820-1822. Architect A. Menelaws, I. A. Ivanov. facades

Special architectural expressiveness has a White Tower (Fig. 3.), built by architect A. Menelas in the 1821-1827.

a)

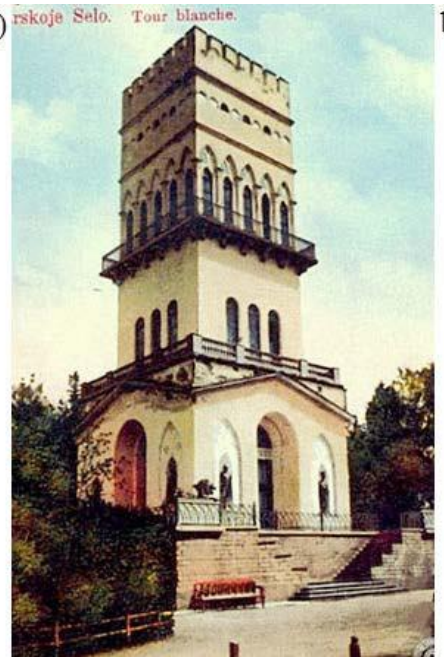

b)

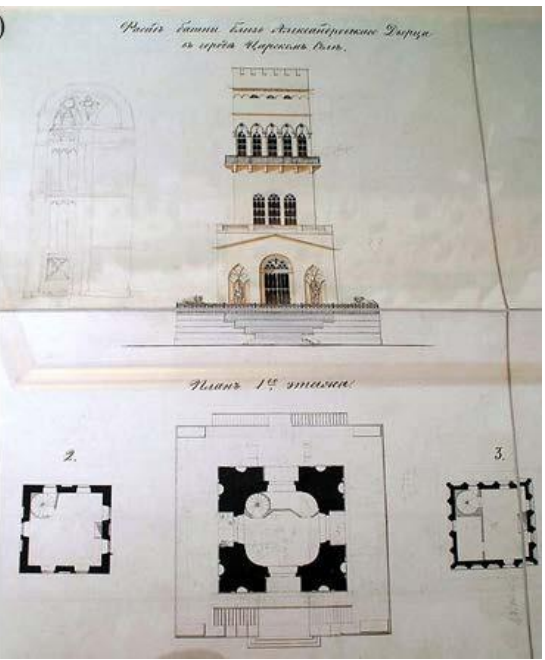

Fig. 3. White Tower. Alexander Park. Tsarskoye Selo. Architect A. Menelaws. 1821-1827. a) General view. Post card of early XX century, b) Facade. Plans. 


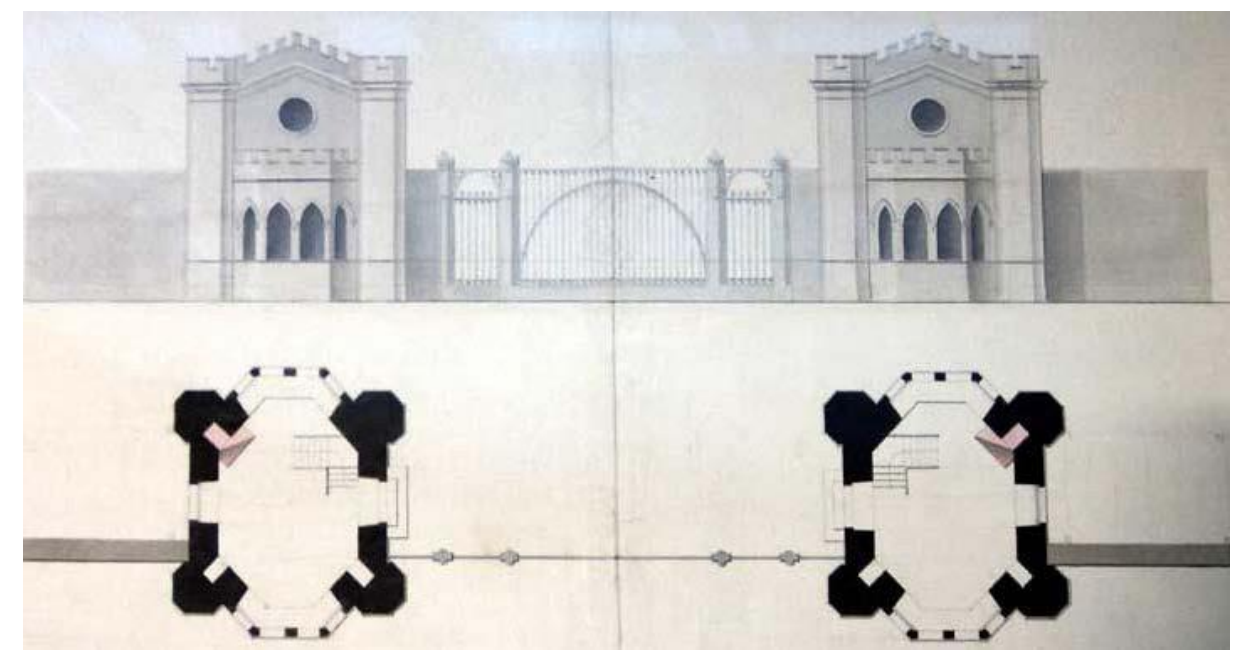

Fig. 4. Elephant (Krasnoselskaya) gates. Alexander Park. Tsarskoye Selo. Architect A. Menelaws. 1823 1826. Project

\section{Materials and Methods}

In this work, the author considers examples associated with difficulties arising from the restoration of urban and suburban estates located within the boundaries of the modern capital megalopolis. Being limited by the format of the paper, the authors will focus on the state of several objects located on the territory of New Moscow. Based on the analysis, the authors intend to provide a general assessment of the state of architectural heritage sites in the capital region.

Below we will consider the status of individual estates located in the new administrative districts of the Russian capital. Their current status and the measures that are being taken to revive them will be compared.

The methods of the study are retrospective analysis of the sources, a comparative historical method, a method of summarizing historical data, a method for predicting and extrapolating trends observed in the restoration sphere in the near future. The authors also adopted the methods of research of legal sciences, consisting in a retrospective analysis of regulatory legal acts, decrees and decisions of the executive branch. In developing recommendations for improving the practice of restoration and reconstruction, the method of modeling legal situations, the method of extrapolating decisions of judicial precedents and a number of others are used. As the source data, the authors use news materials published on the pages of the capital and the Moscow Region mass media, such as "Moscow Today", "Russian House", "Moscow Heritage", "New Districts", "Urban Perspective", etc.

As a source, the Register of Cultural Heritage and a number of other legal acts are used.

\section{The results of the study. City estates as a means of landscaping the megalopolis}

The accession of new territories to the capital megalopolis forced restoration organizations to turn again to the problem of restoration of cultural heritage objects located here, as well as preservation of green areas and natural objects, which became part of 
manor architectural and planning space. According to official sources, 27 identified architectural monuments (including ensembles from several objects) are located in the territory of the Novomoskovsky Administrative District. These include more than ten churches, nine manors (Valuevo, Izvarino, Izmalkovo, Shchapovo, etc.), two manor parks without preserved historical buildings (Troitskoye park in the village Mosrentgen, Yakovlevskoye estate), three memorials and several summer houses of famous persons of Russian culture [5]. When identifying protected sites in New Moscow, the weekly newsletter "Moscow Today" uses a metaphor, calling them "incorruptible places in Russian history." However, the stone structures are "corruptible". The ruins of the Krekshino estate, which gradually disappear due to the nature forces and the inaction of people, have become a symbol of indifference to historical monuments and buildings. The master's house in the Klenovskoye estate was not preserved: the second floor of the building burned down in the 1990s. Only in relation to some of these monuments we can say that in their fate there have been changes for the better. So, after joining the capital city, the official Register of cultural heritage monuments was updated. Art. 20 Federal Law No. 73 "On objects of cultural heritage (historical and cultural monuments) of the peoples of the Russian Federation" establishes that "... maintaining the Register includes registration of the object of cultural heritage in the Register, documentation of the Register, monitoring data on the objects of cultural heritage" [6] .

Monitoring involves the formation and maintenance of records of cultural significance objects in accordance with the Regulation, which was approved by Order of the Ministry of Culture No. 954 of 10/03/11 "On Approving the Regulation on the Unified State Register of Cultural Heritage Objects (Monuments of History and Culture) of the Peoples of the Russian Federation" [7]. Access to information from the CHO Register is open, unless the prohibition of such information is specified in federal laws. Moreover, such access can be obtained on the official portal of the executive authority [8].

The preservation of manor architecture monuments located in the south-west of Moscow is not the same. Along with the well-preserved estates of Ostafyevo, Valuevo, Shchapovo or the main house in the village Krasnoye, we can recall the Krekshino estate, which we just cited as an example, from which there were only ruins. The prospect of restoring such CHOs as buildings on the territory of the former estates of Milyukovo, Pervomaiskoe, to some extent V.P. and V.D. Berg's cottages, today seems very ghostly.

It should be noted that in the official documents a whole range of objects is clearly lacking, which in their age and value are in no way inferior to those listed and described in the Register of cultural heritage objects. The most famous of these monuments, almost abandoned and in need of conservation, is the Trinity Church in the village BerezkiSeversky, founded in 1762 in the estate of Prince S.V. Saltykov, the famous diplomat and favorite of Catherine II, a relative of the sinister landowner [9]. The lack of state protection status actually means for these objects a constant threat of destruction. Property owners or developers who lease land can, on completely legitimate grounds, quickly dismantle an "unnecessary" ancient construction, and it will be impossible to stop them in legal ways. Note that supervisory authorities are often late, facing the fact of damage or partial destruction of even a protected object. Those estates located on the territory of "old" Moscow are not protected from destruction. For example, the unauthorized demolition of a $\mathrm{XIX}^{\text {th }}$ century estate on Bolshaya Ordynka turned into a criminal case for the owner of the LLC "Zolotaya Orda". The documents quoted by the media indicate that "based on the materials of the prosecutor's inspection, the Department of Inquiry of the Ministry of Internal Affairs of the Russian Federation in the Yakimanka district opened a criminal case under part 1 of art. 243 of the Criminal Code of the Russian Federation (destruction of cultural heritage objects)" [10]. 
What can we say about the monuments located on the territory of the new districts of the "First-throned". The Berg estate complex mentioned above, located on the banks of the Desna, is slowly being destroyed. Berg's father's house, built in 1904 according to the project of V. Adamovich, has already completely turned into ruins. The walls of the second house that belonged to his son, squinted strongly. Meanwhile, the monument was a vivid example of the manor architecture of the Art Nouveau era. The state of this wonderful object is alarming even today.

\section{Results. Valuevo and Klenovo as examples of "green architecture" of the XVIII century}

The authors have already noted, that manors that were not abandoned by people but were placed at the disposal of the sanatorium-resort department, or were used by state organizations, and were given to educational or cultural institutions, look much better than the premises left by people. In the south-west of the capital, perhaps the estate of Valuevo is better preserved than others by time and people.

The manor complex has been preserved as it was formed by the beginning of the XIX ${ }^{\text {th }}$ century. The halls of the main palace of the estate are connected to the lobby overlooking the park. The latter at a time when the patron and collector of ancient manuscripts Count A.I. Musin-Pushkin was decorated in the "English" style. The spouse of Count E.A. Musina-Pushkina ordered tree planting, poured artificial hills, and deep ravines crossed the estate itself. The quasi-naturalness of the park was emphasized by paths, a terraced cascade of ponds. In addition to this, garden pavilions were already built in the park at that time. One of these pavilions, the so-called "Hunter's Lodge" with a Tuscan four-column portico, decorates the descent to the small shallow river Likove.

Under the Lepeshkin factory owners, who became the owners of the estate in the second half of the $\mathrm{XX}^{\text {th }}$ century, pompous gates decorated with bronze deer were built, and the doors of the main palace were guarded by lions made in bronze too. The repose of the nouveau riche should have been guarded by awesome monsters. However, predators cast in metal did not save the estate owners from class storms: after the October Revolution, the real estate of the old owners was nationalized.

The ownership of industrial tycoons has acquired new features. The palace and adjacent buildings were transferred to the sanatorium at the Vnukovo airport, and in 1962, the Mosstroy sanatorium was located in it. In this capacity, the estate operates today [11, p. 56].

Today it is important to preserve this work of landscape architecture, open-air sculptures, grottoes and arbors. It is equally important to preserve the qualitative and quantitative characteristics of manor vegetation. After all, the park will make the air around the estate cleaner, while the harmful impurities entering the surface layers of the urban atmosphere even affect the stone, the plastered surfaces of wooden buildings. To the above should be added climate change, which leads to a change in the biocenoses of the park [12, p. 180]. Playing a large role in maintaining the natural balance, manor gardens are involved in the circulation of substances in nature [13].

The examples we have chosen show how difficult and different were the postrevolutionary destinies of estates near Moscow. If in the village Valuevo most of the secular constructions built by their old masters have been preserved, then the estate of the princes Cherkassky today is in ruins. A religious building, a magnificent temple located on the territory of Valuevo was dismantled, and the main architectural decoration of the Klenovskoye settlement - the church of St. Nicholas - is now operating and is the only architectural monument preserved on the territory of the former estate. The temple is an example of the embodiment of the principles of Moscow temple architecture of the second half of XVIII - beginning of the XIX centuries. Just like the Valuevo Palace, the church of 
St. Nicholas is a monument of early classicism. In the beginning of 1990s the premises of the church were transferred to the community of the Russian Orthodox Church (the latter was registered on October 26, 1991, on the day of the celebration of the icon of the Iveron Mother of God).

Another temple, the Protection of the Mother of God in Valuevo, was also built in the traditions of classicism and had individual elements of the Neo-Russian style characteristic of the second half of the XIX ${ }^{\text {th }}$ century, as evidenced by the few photographs of the lost architectural monument. Websites dedicated to the history of the Valuyevo estate, meanwhile, report that the church in the village was repeatedly exposed to the destructive effects of the events of Russian history. The first wooden church of the Protection of the Mother of God in the territory of Valuevo did not survive the Lithuanian invasion. Like other buildings on the territory of Valuevo estate, the stone church of the Protection was badly damaged in 1812: at that time, the French lodged on the territory of Musin-Pushkin estate. During the years of Soviet power, the structure slowly collapsed until it was completely demolished in the beginning of 1970s.

Except the temple in the village Klenovo, which is in good condition after the restoration, nothing from the Cherkassk estate was preserved. Fires, time and, most importantly, indifference of people did not spare the ancient buildings on the estate. In electronic media we read: "As of 2018, only the western part of the estate was preserved, including the ruins of the estate (the second wooden floor of the building burned down in 1992), groups and curtains of old-growth trees, small fragments of alleys, clearings and meadow. The eastern part of the estate is occupied by private residential buildings with personal plots. Eastern stone outhouse with a mezzanine at the turn of the $\mathrm{XIX}^{\text {th }}-\mathrm{XX}^{\text {th }}$ centuries is privately owned. " [14]. At that time, fire investigators had to institute criminal proceedings under article 149 of the RSFSR Criminal Code, which was in force at that time, "Deliberate destruction or damage to property < ..> including by arson".

But history and the capital's media are silent about further actions of the fire service and the police, because it is not clear from the documents cited whether a criminal case was opened under the above article. Who was the owner of the building at that moment in time? Whether there was an arson of the building? And who specifically punished if there was an arson? Most likely, the protocol indicated that the fire occurred due to the decay of the wiring and the building as a whole. The authors have the right to make such a conclusion, relying on an analogy with other similar incidents that did not end with the punishment of those responsible for the arson.

\section{Discussion. Protection and restoration of Moscow estates as an implementation of the principle of cultural preservation}

When analyzing the current state of manor architecture works and evaluating the actions of municipal authorities and owners of objects to protect manor park ensembles located both in the historical center of the Russian capital and on its outskirts - in the southwestern districts, in 2011 annexed to the Moscow megalopolis, there are problems that cause debate. Despite the presence of normative legal acts aimed at the protection of cultural heritage objects, manor complexes continue to collapse.

The culprits of this are most often unscrupulous tenants, developers, residents themselves. Enlightenment work, a story about these monuments in the media, a comprehensive study and description of landscape and natural parks in Moscow and the Moscow Region and still preserved historical buildings and structures should change the situation. 


\section{Conclusion}

This article reflects the state of manor park complexes located in the historical center of the Russian capital, as well as in the new territories of Moscow. The annexation of territories in the south-west of the Moscow region in 2011 led to a change in the legal status of the estate and park complexes located here. The authors of the paper showed what the state of the suburban palaces and the surrounding parkland turned out to be on the eve of the inclusion of new territories in the capital metropolis. The state of the old estates and their preservation have not undergone major changes today.

The given examples show that the status of protected objects is not always protect this monuments from unauthorized demolition and destruction. At the same time, the paper reveals the role of manor-park ensembles in the formation of a biosphere-compatible environment of the capital metropolis, increasing the species diversity of urban perennials that grow on the territory of estates.

\section{References}

1. K. Schloegel, Beitrage zur Entstehung moderner Urbanitat. Marjampole oder Europas Wiederkers aus dem Geist der Staedte (Wien, 2005)

2. V. Soloukhin. Slavic notebook (Moscow, 1981)

3. A. Avakov, MC. 3 (2018) C.3.

4. Greater Moscow [Topic: Walking with history]. 158, 12 (2018)

5. https://mosgazeta.ru

6. Federal Law of June 25, 2002 N 73-FL (as amended on July 18, 2019) “On Objects of Cultural Heritage (Monuments of History and Culture) of the Peoples of the Russian Federation".

7. Order of the Ministry of Culture of Russia dated 03.10.2011 N 954 (as amended on August 05, 2015) "On the Approval of the Regulation on the Unified State Register of Cultural Heritage Sites (Historical and Cultural Monuments) of the Peoples of the Russian Federation" (Registered in the Ministry of Justice of Russia on December 19, 2011 N 22670)

8. https://data.mos.ru/opendata/530

9. https://mosgazeta.ru/церковь-в-березках-и-москомнаследие/

10. http://msk.newsru.com/article/17jul2014/ordynka_ugol.html

11. E. Gershkovich, Moscow Heritage. New Moscow. 30, 56 (2013)

12. F.M. Diaghilev, Concepts of Modern Natural Science (Ed. IMPE, Moscow, 1998)

13. G.I. Ivanova, ICNC-FSKD $2017-13^{\text {th }}$ International Conference on Natural Computation Fuzzy Systems and Knowledge Discovery, 186 (2017)

14. http://wikimapia.org/32469455/ru/Remains-estates-Klenovo

15. Igor Yamshanov, Vasiliy Goryunov, Vera Murgul, Procedia Engineering 117, 675 684 (2015) doi.org/10.1016/j.proeng.2015.08.232 